Chair of Comparative Public Policy and Administration Department of Politics and Management University of Konstanz

\title{
Rhetoric or Reality? \\ 'New Governance' \\ in EU Environmental Policy
}

Katharina Holzinger, Christoph Knill

and Ansgar Schäfer

Universität

Konstanz 
Chair of Comparative Public Policy and Administration Department of Politics and Management

University of Konstanz

Working Paper 04/2006

Rhetoric or Reality?

'New Governance' in EU Environmental Policy

Katharina Holzinger, Christoph Knill and Ansgar Schäfer

First publ. in:

European Law Journal 12 (2006), 3, pp. 403-420

Konstanzer Online-Publikations-System (KOPS)

URL: http://www.ub.uni-konstanz.de/kops/volltexte/2008/6336/

URN: http://nbn-resolving.de/urn:nbn:de:bsz:352-opus-63367

\section{Contact}

Prof. Dr. Christoph Knill

Chair of Comparative Public Policy

and Administration

Box D 91

D-78457 Konstanz

Germany

Phone ++497531 885597

Fax ++ 497531882381

christoph.knill@uni-konstanz.de

University of Konstanz

www.uni-konstanz.de

Department of Politics and Management www.uni-konstanz.de/sektionen/polver

Chair of Comparative Public Policy and Administration www.uni-konstanz.de/FuF/Verwiss/knill 


\title{
Rhetoric or Reality? \\ 'New Governance' in EU Environmental Policy
}

\author{
Katharina Holzinger, Hamburg University \\ Christoph Knill, University of Konstanz \\ Ansgar Schäfer, University of Jena
}

\begin{abstract}
When scrutinizing the literature on EU environmental policy, it becomes apparent that there has been a comprehensive transition in regulatory ideas during the last two decades. At the core of these changes is the abolition of traditional patterns of interventionist command-and-control regulation in favor of economic and "contextoriented" instruments. In view of these developments, this article has two objectives: first, it looks into which causes and factors initiated these discussions; second, it analyzes the effects these reform ideas had on patterns of regulation. As will be shown, changes in regulatory ideas are only partially expressed in changes in policy instruments.
\end{abstract}

\section{Introduction}

When scrutinizing the literature on environmental policy in the European Union (EU), it becomes apparent that there has been a comprehensive transition in regulatory ideas since the beginning of the 1990s. Authors are talking of "new instruments" (Héritier 2002; Jordan et al. 2003; Rittberger and Richardson 2003) or even of the "transformation of the environmental governance in the EU" (Lenschow 1999). At the core of these changes is the abolition of traditional patterns of command-and-control regulation in favor of "context-oriented" instruments, emphasizing close cooperation of public and private actors in the formulation and implementation of EU environmental policy.

The great scientific resonance that this reform development has found ought not, however, blind us to the fact that there was already a broad discussion of environmental regulation in the 1980s; this was primarily dealt with in environmental economics and at the level of international organizations (OECD 1981b). This earlier discussion was less concerned with context-oriented forms of regulation, but with 
introducing economic instruments, which were considered substantially more efficient than interventionist measures.

Against the background of these developments, this article has two objectives: first, it looks into which causes and factors initiated these two mentioned discussions; second, it analyzes the effects these reform ideas had on actual patterns of regulation. To what extent and in which direction do new policy ideas actually result in the adoption of new policy instruments?

If one considers the various action programs in which the strategic orientation of the EU environmental policy is defined for the middle term, a relatively sound finding regarding underlying regulatory ideas becomes apparent. The political demands for both economic and context-oriented instruments are clearly reflected in the regulatory ideas formulated in the individual action programs. Both in the mid-1980s and at the beginning of the 1990s, an explicit paradigm change in regulatory policy was demanded in the respective programs; this came to expression in formulations about "second-generation" instruments or "new governance approaches".

This change in regulatory ideas, however, is only partially expressed in changes in concrete instruments introduced in EU environmental law (cf. Rittberger and Richardson 2003). The discrepancy between political declarations in the action programs and their actual implementation is especially obvious in respect to economic instruments. However, the introduction of context-oriented instruments has increased relatively little, as well, measured on the political demands. Interventionist instruments still constitute the dominant form of environmental regulation in the EU.

In the following section, we first analyze the reception of economic and contextoriented regulatory ideas in the various environmental policy action programs, and investigate the causes favorable to these wide-reaching changes. Building upon this, in section three we explore whether and to what extent the changes in ideas have affected the choice and the allocation of policy instruments. Section four is dedicated to the explanation of the empirical findings. The general outcomes resulting from this analysis are summarized in section five. 


\section{The Call for "New Instruments": Changes in Ideas and Conditions of Regulation}

EU environmental policy developed as a policy area in its own right from the early 1970s onwards. Initial policies of the Community were primarily command and control instruments, implying a highly interventionist approach (Rehbinder and Stewart 1985, chapter IV). Since the mid-1980s, however, new regulatory ideas have appeared which aim at re-orienting the choice of environmental policy instruments. Two strands are to be differentiated: beginning in the mid-1980s the EU Commission advocated "economic incentive instruments", such as environmental taxes, tradable permits or risk liability schemes. At the beginning of the 1990s, primarily "contextoriented instruments" were suggested. These aim to leave the member states more discretion in the implementation, to include the addressees in policy formulation and enforcement, and to prescribe administrative procedures rather than substantial outcomes to be achieved.

\subsection{Regulation by Economic Incentives}

The introduction of economic instruments was first proposed in the third environmental action program of the Community (1982-1986) ${ }^{1}$. The fourth action program (1987-1992) ${ }^{2}$ dealt in detail with economic instruments. Emission taxes, emissions certificates, state aid, negotiable deposit permits, voluntary agreements with the polluters, and stricter liability laws were specified. How did this new orientation in the use of instruments come about, and which ideas are behind the mentioned instruments?

Instruments such as environmental taxes, tradable permits, subsidies and voluntary agreements are among the measures in the "classical canon" proposed by environmental economics as superior forms of regulation, especially when compared to hierarchical intervention (Binder 1999). The discussion about economic instruments was especially intense between 1975 and 1985. In the second half of the 1980s this canon was expanded to include risk liability schemes and fund solutions to

Official Journal C 46, 17.02.1983.

2 Official Journal C 328, 7.12.1987. 
compensate for environmental damages (Endres 2000). There are primarily three expectations connected with economic instruments:

First, these instruments correspond to the polluter-pays principle, i.e. the normative distribution principle that the polluters have to bear the costs of the pollution they have caused. By introducing environmental taxes, tradable permits, subsidies, environmental funds or risk liability schemes, the polluter not only carries the costs of avoiding environmental pollution to a certain limit (usually by some technical device), but also the costs of the residual pollution. In the case of interventionist instruments (e.g. environmental standards), by contrast, the polluter carries only the costs for avoiding environmental pollution insofar as the standard requires that this be avoided. Economic instruments thus implement the polluter-pays principle in a much more encompassing way as it is the case for interventionist measures. The only exception is subsidies: while they are in fact classified as economic instruments, they are not in accord with the polluter-pays principle but in accord with the common cost principle.

Second, economic instruments are suited to guarantee the optimal allocation of environmental resources. Taxes, permits and fund solutions are more flexible than regulatory standards and requirements. Environmental protection investments are used where there costs are lowest: As long as the investments to avoid environmental pollution are lower than the costs of taxes or permits, environmental pollution will be avoided; otherwise companies will pay for the residual pollution. In this way, the operational and economic costs of environmental protection will be minimized (Frey 1972; Siebert 1976; Endres 2000). The same applies for emission subsidies. For regulatory standards, by contrast, everyone addressed by the provision is to carry out preventative measures to the same degree, regardless of the individual costs, which might vary greatly (Bea 1973).

Third, the economic instruments are dynamically efficient. The fact that, when these instruments are used, the residual pollution still has to be paid for gives those addressed by the provisions an incentive to be innovative. As long as a tax must be paid, a pollution permit must be purchased, or one is liable to pay damages for residual pollution, there is an incentive to develop more comprehensive mechanisms to avoid pollution. Regulatory standards do not give rise to this incentive. 
In particular, in the mid-1980s the first two expectations induced the EU Commission to take over the regulatory ideas from environmental economics. Two principles connected with these two expectations - i.e. "the principle of compatibility between ecology and the economy" and the polluter-pays principle - can already be found in the first and second action programs for environmental protection. Both principles, however, only became weighty in the 1980s, first the "principle of compatibility between ecology and economy" and later the polluter-pays principle.

The "principle of compatibility between ecology and the economy" was formulated in the first action program. ${ }^{3}$ Against the background of worsened global economic conditions, this principle was emphasized more strongly in the third action program ${ }^{4}$. The Commission feared cut backs in environmental policy because of the worsened economic conditions. It was significant that environmental protection could be carried out cost-effectively, and under certain circumstances could even contribute to solving economic problems.

This change in the conditions of regulation prompted the Commission to deal much more with the question of the most cost-effective instruments. In its interpretation of the third action program, it argues that it is important to achieve the optimal allocation of the resources "in the broadest sense of the term". In this context, the Commission proposed applying a stricter form of the polluter-pays principle. Besides, it was proposed that taxes and permits be introduced. This way, market principles could be used to achieve generally accepted environmental objectives (European Commission 1984: 84).

In the development of the third and fourth action program, the Commission pursued the goal implied in the new interpretation of the polluter-pays principle. The initial definition as stated in the first action program ${ }^{5}$ implied first, that the polluter-pays principle only refers to the costs of avoiding pollution and not to the entire costs of the pollution. Second, exceptions were permitted as long as they did not impair the general market functions. In principle, however, financial aid does not comply with the polluter-pays principle. Third, this interpretation of the polluter-pays principle was not applicable to international pollution.

3 Official Journal C 112, 20.12.1973; cf. European Commission (1984: 15). 
In the third and fourth action programs, the Commission developed an expanded definition of the principle, which was to be achieved with economic instruments. To reduce social costs emerging from residual pollution,

[c]harges constitute one of the instruments for the application of the polluter-pays principle and they can provide an incentive to the introduction of antipollution measures to reinforce the application of standards and stimulate innovation, especially if residual pollution is also covered by the charge. It is necessary therefore to study carefully the fields where charging systems would allow the achievement of the objectives of environment policy more efficiently. ${ }^{6}$

Beyond that, the Commission aimed to make the polluter-pays principle applicable to transboundary pollution. It specified the context of a new interpretation of the polluterpays principle with "new instruments", including in particular environmental taxes and charges, liability and funding schemes as well as international agreements (IfoInstitute 1989: 5). In the fourth action program, the same instruments are listed, expanded to include state aid, tradable permits and negotiated agreements with polluters. $^{7}$

Which changes in regulatory conditions prompted the Commission to expand the definition of the polluter-pays principle and the palette of environmental policy instruments? Most important in this respect are the changes in the legal framework, political and ideological developments outside of the Community as well as a changed problem structure and new environmental priorities in the Community.

First, the polluter-pays principle was integrated into the European Treaties with the Single European Act (Art. 174 [ex Art. 130r]). The Community was thus bound, without restrictions, to the polluter-pays principle. The Commission took this as an occasion to formulate a broader polluter-pays principle, which would serve as the standard for application, hence avoiding different interpretations of the principle (should it only cover the costs for avoiding pollution or also include residual costs) in the member states.

\footnotetext{
Official Journal C 46, 17.02.1983: 4-5.

Official Journal C 112, 20.12.1973: 6, authors' translation.

Official Journal C 46, 17.02.1983: 8.

Official Journal C 328, 7.12.1987.
} 
Second, in the mid-1980s, the polluter-pays principle was also intensively discussed in other international organizations, especially within the framework of the OECD. Various studies on its development were carried out (OECD 1981a and 1981b, OECD 1994; Opschoor and Vos 1989). Above all, the international and transboundary application of the polluter-pays principle was dealt with at this level.

Third, in the 1980s there was a broad public discussion about the compatibility between environmental protection and the goals of economic growth. At the same time, there was a shift in the global trend of the macroeconomic philosophies: liberalization, deregulation and a "return to the market" were the new catchwords. This created a climate in which the plea for "economic", cost-effective and marketconforming instruments fits well.

Fourth, environmental problems of the early 1970s were different from those that were perceived as the most dramatic at the end of the 1980s. Among the newly perceived problems were hazardous waste and soil pollution, cumulative pollution (soil, water and the green house effect) and pollution from diffuse sources, which no individual polluter is held accountable for. To finance the abolition of hazardous waste, contaminated land and pollution from diffuse sources, fund solutions and liability schemes were established in the United States and some European states. The Commission was very responsive to these developments.

\subsection{Context-oriented Regulation}

The fifth action program (1993-2000) ${ }^{8}$ marks a second reorientation in EU environmental regulation. On the one hand, this becomes apparent in the fact that there are fewer references to concrete environmental problems than in earlier programs. By contrast, the focus is on principles on which the future environmental policy of the EU should be based. Instead of a problem-oriented perspective we find a primarily governance-related conception (Weale et al. 2000: 61). Central to the latter is the principle of "sustainable and environmentally suited development", on the basis of which economic growth and environmental protection are to be brought into harmony with one another.

8 Official Journal C 138, 17.5.1993. 
On the other hand, the ideas developed in the fifth action program reflect a major departure from approaches propagated in earlier programs. Previously dominant approaches, which essentially were based on forms of hierarchical intervention, are to be replaced or complemented with new forms of context-oriented instruments (Knill and Lenschow 2000). This comprehensive change in the dominant ideas is characterized by various components.

First, effective regulation is to be guaranteed by the most comprehensive collaboration possible between public and private actors at the various institutional levels during policy formulation and implementation. The focus is not so much on developing regulative measures as on integrating and consulting with the actors concerned. The "shared responsibility" of all actors is in the foreground; this ought to be achieved by intensive dialogue with the addressees and the responsible authorities.

Up to the present, environmental protection in the Community has mainly been based on a legislative approach ('top-down'). The new strategy advanced in this Programme implies the involvement of all economic and social partners ('bottom-up'). ${ }^{9}$

Second, achieving this requires that the involved actors have enough discretion to optimally align their respective activities with the conditions of the specific political, social and economic contexts that exist at the national, regional or local levels. Thereby, the fifth action program stands in contrast to the orientation emphasized in the third action program, in accord with which environmental-policy problems were to be surmounted with uniform emissions thresholds (Johnson and Corcelle 1989: 17). The result of the detailed European specifications was that member states only had a narrow scope in which to adapt the European specifications to the nationally varying conditions (Knill and Lenschow 2000).

A third characteristic of regulatory change implied by the fifth action program is the development of "new instruments" to achieve the above-mentioned goals. The instruments proposed in this context all aim to leave responsible authorities and addressees broad discretion for concrete implementation. This ought to be reached by forgoing detailed specifications of contents (such as emission standards). The emphasis is on defining broad objectives (quality objectives) in order to grant the

9 Official Journal C 138, 17.5.1993: 17. 
member states greater scope of action in choosing the means to reach these objectives. Beyond this, environmental instruments shall be largely limited to procedural guidelines, without however providing substantial objectives regarding the results of these procedures. The Commission hoped that this makes greater flexibility possible in adapting to future developments and national contextual conditions (Héritier et al. 1996).

A second general objective of the "new instruments" is to explicitly change the national contextual conditions in order to achieve a more effective implementation of the regulatory goals. The instruments ought to create positive incentives for societal actors to voluntarily cooperate and participate in formulating and implementing European environmental policy. In this context, two developments can be differentiated:

For one, the Commission emphasizes the development of instruments to improve rights to information and participation of a large group of different state and private actors (Mol et al. 2000). It also emphasized that through wide-reaching information and the use of publicity the general environmental consciousness and the acceptance of the required environmental measures could be rigorously supported. ${ }^{10}$

On the other hand, the forms of hierarchical intervention ought to be increasingly complemented with cooperative arrangements and legally non-binding agreements between public and private actors. This applies especially to the reduction of industrially caused environmental pollution, where voluntary agreements with industry and forms of private self-regulation should play a major role:

The new approach implies, in particular, a reinforcement of the dialogue with industry and the encouragement, in appropriate circumstances, of voluntary agreements and other forms of self-regulation. ${ }^{11}$

What background conditions have been favorable to this deep-reaching transition in the regulatory ideas? A first factor favoring these changes refers to the growing politicization of the EU's limited policy-making capacity against the background of an increasing number of transboundary environmental problems. Thus in the face of diverse national conditions and interest constellations, the detailed specification of

$\overline{10}$ Official Journal C 328, 7.12.1987. 
regulatory policies underlying the interventionist approach implied many drawn-out and problematic decision-making processes at the European level. Interventionist regulation thus implied severe disadvantages in terms of the environmental policymaking capacity of the EU.

Through restricting regulatory requirements to generally defined targets, by contrast, the complexity of the European decision-making process was to be reduced. Beyond that, it was hoped that, by surpassing drawn-out and complex European legislative processes through broadly using voluntary agreements with industry there would be greater decision-making capacity and adaptive flexibility in European environmental policy (Héritier 2002; Mol et al. 2000).

A second problem that is to be overcome by the transition from interventionist to context-oriented instruments regards the implementation deficit in European environmental policy. Even though this problem was long acknowledged, it became significant on the political agenda only at the beginning of the 1990s, because some member states, given the negative results of implementation, generally questioned the legitimacy of the European environmental policy and pushed to "re-nationalize" the regulative competencies (Krämer 1996; Jordan 1999).

Despite very detailed and ambitious policy specifications, problems related to the ineffective implementation of European policies at the national level continually increased (European Commission 1996). Not only did the comprehensive monitoring of EU requirements prove to be difficult, but also the fact that - in the face of the varying geographic, political, social and economic conditions at the domestic level the detailed rules did not always represent the most effective way to achieve the policy results that were aimed at (Knill and Lenschow 2000).

New regulatory approaches, which explicitly aimed to take nationally diverse conditions into consideration, were to be used in an attempt to reduce these implementation problems. Beyond that, it was presupposed that including policy addressees in formulating and implementing EU policies would lead to greater acceptance and thus to effective implementation. ${ }^{12}$

11 Official Journal C 138, 17.5.1993: 14.

12 Official Journal C 138, 17.5.1993: 17. 
A third factor refers to the subsidiarity principle which was not only laid down as an environmental policy principle in the EU, but a general principle of action with the SEA and the Maastricht Treaty. With that, adherence to interventionist models, which strongly encroach upon the national scope of action, could hardly continue to be politically legitimated. Insofar, the subsidiarity principle favored the development of new models of regulation, which would merely prescribe the member states broad targets, but not the means to achieve these targets (Collier 1998).

Fourth, the changes in the EU environmental policy resonated well with a more general and global reform wave, characterized by catchwords such as privatization, liberalization, the withdrawal of the state and new public management. The goals regarding the development of less bureaucratic, more flexible and more effective concepts, all of which arose from this general reform development, favored and legitimized the formation of synchronized patterns of context-oriented regulation at the European level (Lenschow 1999: 40-41).

This development was reinforced by a Commission-ordered study, which among other things, analyzed the repercussions of European and national environmental legislation on the job market and the economic competitiveness of the member states (Collier 1998: 15). The Molitor report, published in 1995, called for a new approach to environmental regulation, which specifically was to include greater scope for the national implementation of European laws and more flexible and less hierarchical forms of intervention (European Commission 1995). In this way, it was to be ensured that the EU environmental policy had no negative repercussions on the international competitiveness of the European economy.

In sum, our considerations show that since the mid-1980s two general lines of development can be observed regarding the development of EU environmental regulation. Both depict a close connection between changes in the politically perceived or defined regulatory conditions and the observable transition in regulatory ideas that transcend the diverse environmental action programs.

The interventionist philosophy, which earmarked the EU environmental policy from the beginning of the 1970s, was initially called into question as economic instruments were accentuated: this was especially evident in the third and fourth action programs. In the fifth action program, at the beginning of the 1990s, there was once again a 
new orientation towards ideas of context-oriented regulation. The focal point was cooperation between public and private actors in formulating and implementing European environmental policy as well as the flexible development of policies against the background of diverging conditions at the national and sub-national levels.

\section{The Development of the Use of Instruments from 1967-2000: Changes in Modes of Regulation}

Although these changes in regulatory ideas in the respective action programs of the EU can be clearly understood and substantiated, this must not necessarily imply that this transition is actually reflected in the empirically observable changes in policy instruments, as the environmental action programs of the EU are merely declarations of political intentions, in which general guidelines and goals are defined. This, however, by no means gives rise to a legal obligation to actually pass such measures. Against this background, in the following section it will be more closely investigated whether and to which extent the change in ideas has been accompanied by corresponding shifts in regulatory modes.

\subsection{Data Basis}

To do so, we studied the development of the use of instruments in EU environmental policy from 1967 until 2000. 1967 is the year in which the first environmental policies were passed. 2000 was the last year of the fifth action program. All of the measures in this time period that followed explicit environmental policy objectives were investigated. The basis for the data is the systematic compilation of EU environmental law by Haigh (2000). Even though this collection is incomplete, it does include most of EU legal activities with regard to the environment, and, in any case, all of the important ones, which were passed in the EU in this time period. In addition, the legal sources themselves were referred to, and information from the Commission's General Directorate for the Environment was also consulted.

A simple listing of the instruments implies that they are weighted equally. Differences in the relevance of the individual measures are not apprehended in this way. Yet, this procedure appears justified given the difficulties in finding clear criteria for 
determining relevance. Problems arise not only in the choice of criteria (should the number of actors affected serve as the basis, the benefits for the environment, the initial adoption of a measure or the continuation of one?), but also in the process of evaluating them.

The legal acts were classified according to the central types of instruments (standards, financial aid, right to information, etc.) and modes of regulation (interventionist, economic, context-oriented). Those regulatory techniques with the priority of reaching the objectives of the measure were classified as central instruments. This procedure implies that accompanying measures and supplementary provisions are not listed. The number of such secondary measures per legal act varies considerably. They are largely related to the procedural specifications of interventionist measures such as the right to information vis-à-vis the Commission.

\subsection{Empirical Findings}

To determine whether and to what extent the changes in regulatory ideas resulted in concrete changes of policy, we listed all EU environmental legal acts that were passed in the time period under study in reference to their central instruments. On the basis of the differentiation between the various regulatory ideas from the previous section, the latter can be subdivided into three broader modes of regulation.

The first mode refers to interventionist instruments, which encompass not only emission and quality standards, but also technical specifications, prohibitions and other restrictions and obligations. In the time period under investigation the second type of economic instruments only appeared at the European level in the form of financial assistance. In individual directives, such as the ones on car emissions or on the disposal of used oil, member states are explicitly authorized to introduce economic incentives, such as tax reductions. This does not mean, however, that economic instruments are introduced at the European level. Rather, the definition of EU-wide emission or technical standards is the focal point of these measures. Included among the third regulatory mode, i.e. context-oriented instruments, are quality targets, certifications, the right to information, campaigns and appeals, 
voluntary agreements as well as measures that aim at improving the coordination of the environmental policy activities of the member states.

Table 1. Share of the various instruments and the governance modes in EU environmental policy

\begin{tabular}{|l|r|r|}
\hline Governance Mode/Type of Instrument & Absolute Frequency & Relative Share [\%] \\
\hline Interventionist instruments & 51 & 19.5 \\
Emission standards & 34 & 13.0 \\
Quality standards & 14 & 5.4 \\
Technical specifications & 38 & 14.6 \\
Prohibitions (products, assets) & 17 & 6.5 \\
Production and trade restrictions & 8 & 3.1 \\
Declaration obligations & 5 & 1.9 \\
Preventative obligations & 54 & 20.7 \\
Information and data inquiry obligations & & 4.2 \\
\hline Economic instruments & 11 & 3.1 \\
Financial aid & & 0.8 \\
\hline Context-oriented instruments & 8 & 0.8 \\
Quality targets & 2 & 1.1 \\
Certification & 2 & 3.8 \\
Information rights & 3 & 1.5 \\
Campaigns, appeals & 10 & $\mathbf{1 0 0 . 0}$ \\
Voluntary agreements & 4 & 84.7 \\
Coordination of Member State policies & $\mathbf{2 6 1}$ & 2.1 \\
\hline Total & 229 & \\
Interventionist instruments & 11 & \\
Economic instruments & 21 & \\
Context-oriented instruments & & \\
\hline
\end{tabular}

The data clearly demonstrate that - regardless of the innovation in ideas interventionist instruments still play a dominant role. Although the action programs strongly emphasized the need to introduce economic instruments, this is hardly reflected in any noteworthy political measures. In addition, financial assistance, the only economic instrument used in the period under study, is hardly up to the goals formulated with the expanded polluter-pays principle. In other words: the economic instruments passed by the EU were not really the instruments propagated in the third and fourth action programs. The planned introduction of $\mathrm{CO}_{2} /$ Energy tax failed in the early 1990s because of the resistance of the member states. The only present approach for introducing economic instruments appears in the measures adopted in 2003 for implementing the Kyoto Protocol by creating an "EU market" for $\mathrm{CO}_{2}$ emissions, using tradable permits. 
Also the share of context-oriented instruments appears to be relatively small, especially if one considers that the fifth action program was supposed to comprehensively expand such regulatory modes. Although the discrepancy between ideas and modes of regulation is not quite as clear as it is for economic instruments, it can nonetheless be maintained that the programmatic regulatory reorientation, as it has emerged since the mid-1980s in the individual action programs, has thus far obviously not detracted from the dominance of the interventionist instruments.

Although the share of economic and context-oriented instruments seems relatively small in general, this must not necessarily mean that the development of the new regulatory ideas is of little significance for the allocation of environmental instruments in the EU. The influence of new ideas might become apparent insofar, as the relative share of economic and context-oriented regulation increased over time. This relationship is analyzed in table 2 , which summarizes the development of the relative shares of the various regulatory modes for the time period of the individual action programs and for the period just previous to these.

Table 2. Share of the different governance types in the different time periods (with reference to the action programmes)

\begin{tabular}{|l|c|c|c|c|}
\hline \multirow{2}{*}{ Time Period } & \multicolumn{3}{|c|}{ Governance Type } \\
\cline { 2 - 5 } & $\begin{array}{c}\text { Interventionist } \\
\%\end{array}$ & $\begin{array}{c}\text { Economic } \\
\%\end{array}$ & $\begin{array}{c}\text { Context-oriented } \\
\%\end{array}$ & $\begin{array}{c}\text { Total } \\
\%\end{array}$ \\
\hline $1967-1972$ & 100.0 & 0.0 & 0.0 & 100.0 \\
$1973-1976\left(1^{\text {st }} \mathrm{AP}\right)$ & 100.0 & 0.0 & 0.0 & 100.0 \\
$1977-1981\left(2^{\text {nd }} \mathrm{AP}\right)$ & 88.0 & 0.0 & 12.0 & 100.0 \\
$1982-1986\left(3^{\text {rd }} \mathrm{AP}\right)$ & 100.0 & 0.0 & 0.0 & 100.0 \\
$1987-1992\left(4^{\text {th }} \mathrm{AP}\right)$ & 82.4 & 2.9 & 14.7 & 100.0 \\
$1993-2000\left(5^{\text {th }} \mathrm{AP}\right)$ & 78.6 & 7.7 & 13.7 & 100.0 \\
\hline
\end{tabular}

In fact, we see that before the adoption of the fourth action program, EU environmental policy basically relied upon interventionist regulation. Certain deviations from this pattern can only be observed during the second action program, in which $12 \%$ of the measures were already context-oriented. These were quality targets and information campaigns. Economic instruments were first used during the fourth action program, and there was an increase in their use during the fifth action program. This, however, was merely a matter of financial assistance - as is made clear in table 1. Context-oriented instruments were again used during the fourth and 
fifth action programs. Contrary to the declaration of the fifth action program, however, there is no increase in the use of context-oriented instruments in this final phase, although various new instruments, such as voluntary agreements, certification or the right to information, have been introduced for the first time.

As a whole, since the mid-1980s there has been a reduction in the use of interventionist regulation in comparison to economic and context-oriented instruments. However, this development cannot be immediately connected with the respective political declarations in the action programs. This is demonstrated by the fact that the use of context-oriented instruments already increased during the fourth action program, although corresponding ideas were only introduced with the fifth program. The reorientation of ideas with the fifth action program may thus be understood as a confirmation of a development that had already appeared earlier.

\section{Explaining the Gap between Ideas and Their Application}

The analysis of EU environmental policy between 1967 and 2000 has shown that the discussion about the new forms of regulation in fact only led to minor changes in the instruments employed. The goals aimed at in the discussion about economic instruments were not achieved at all. Those related to the goals of context-oriented regulation were only partially achieved. Obviously, there was a marked change in ideas of environmental regulation. But there was no corresponding change in the regulatory modes actually used. What are the factors that account for this gap between the emergence of regulatory ideas and their limited application in practice?

\subsection{Economic Integration versus Environmental Regulation:}

\section{Restrictions on Instrument Substitution}

A first factor to explain the still unchallenged dominance of interventionist regulation in EU environmental policy refers to the fact that there is only limited room for substitution of interventionist regulation by economic or context-oriented approaches. These restrictions emerge from harmonization objectives of the member states and the Commission in completing the internal market. 
With respect to the substitution of interventionist regulation by context-orientation, important restrictions emerge from the objective of harmonization underlying many environmental policies at the European level. As context-oriented instruments explicitly emphasize discretion for national adjustment and the definition of domestic regulatory requirements within rather broad objectives and guidelines, they are hardly suitable in order to achieve harmonized levels of national regulation. It is rather their basic objective to allow for regulatory variety.

In many cases, however, harmonization constitutes a central motivation of EU environmental policy. Harmonization arguments are particularly pronounced in the case of environmental product standards (e.g. emission standards for cars). The establishment of the internal market requires the harmonization of standards in order to avoid trade barriers and distortion of competition. The trade-oriented rationale was especially dominant as long as there was no explicit legal basis for the development of EU environmental policy. Environmental measures had to be legitimated by economic rather than environmental objectives - a constellation that changed only with the Treaty revisions established in the 1987 SEA. Moreover, national industries typically have a common interest in harmonizing product standards, as the adjustment of product characteristics to different national standards would increase production costs. As a result, industry in both high-regulating and low-regulating countries benefits from uniform product standards (Scharpf 1997; Holzinger 2002).

As regards process standards, high-regulating countries, in many instances, display a strong interest in the harmonization of environmental standards for production processes (e.g. emissions form large combustion plants). They want to avoid economic disadvantages for their industries subject to competition from their counterparts in low-regulating countries. Although the low-regulating member states might strongly resist such efforts (given the implied loss of competitive advantages), the EU has adopted a considerable amount of environmental process standards. This result, which departs from more skeptical expectations of theories of regulatory competition (Scharpf 1997; Holzinger 2002), can be understood against the background of the particular dynamics underlying EU environmental policy-making, including, in particular, compensation payments to potential harmonization losers, package deals as well as first-mover advantages for member states seeking to establish innovative regulatory approaches at the European level (Héritier et al. 
1996). Taken together, these aspects might explain that high-regulating member states to a considerable extent succeeded in establishing harmonized process standards at the EU level.

From the interventionist measures investigated in this article, almost 45\% (103 policies out a total of 229) define environmental product standards. Another 35\% (80 policies) refer to process standards. This means that by far the largest part (80\%) of EU environmental policy is not only based on the objective of environmental protection, but also characterized by a strong interest in harmonizing domestic standards. Only $20 \%$ (46 interventionist policies) are neither linked to product nor to process regulation and hence have no impact on competition within the internal market. It is only for these policies that context-oriented instruments constitute a feasible alternative. For most of the existing policies, however, context-oriented instruments interfere with underlying harmonization goals, with substitution offering no appropriate option.

Certain restrictions also exist for the substitution of interventionist regulation by economic instruments. In the literature, it is generally argued that the comparative advantage of economic instruments over interventionist regulation is confined to specific constellations in which instruments are characterized by the common objective of reducing or stabilizing maximum emission levels for a given region (Endres 2000: 117). The total of emissions of all polluters in a region shall be restricted to a certain limit. The whole scientific discussion on potential benefits of economic instruments rests on the assumption that they are applied in this specific context.

As a consequence, economic instruments constitute a viable alternative to hierarchical intervention only in cases in which environmental regulations are directed at the achievements of clearly defined objectives concerning emission or environmental quality standards for a certain region. Following the classification of environmental instruments in table 1, this constellation applies to 85 (51 emission standards and 34 quality standards) of the 229 interventionist policies investigated, implying that around $38 \%$ of the interventionist measures can be adequately substituted by economic instruments. By contrast, economic instruments can hardly be seen as feasible option to replace other types of interventionist regulation, such as 
technical specifications, prohibitions, production and trade restrictions, declaration obligations or information obligations. In these constellations, the underling regulatory objectives can hardly be achieved by market-oriented principles as applied in environmental taxes or tradable emission licenses.

The above considerations show that there are important restrictions on the complete substitution of interventionist regulation by context-oriented or economic instruments. Restrictions are particularly severe for context-oriented instruments, given their interference with harmonization objectives underlying around $80 \%$ of the interventionist policies. Restrictions emerging from the objective of economic integration thus constitute a quite powerful and plausible explanation to account for the small share of context-oriented measures in EU environmental policy. The explanatory power of this argument is much lower, however, when it comes to economic instruments. Although certain limits for replacing interventionist regulations also exist in this case, they are less pronounced. One therefore should expect a considerably higher share of economic instruments, especially when compared to context-oriented measures. As demonstrated by our data, however, this is not the case. Economic instruments play an even minor role in EU environmental policy than context-oriented instruments. In the following, we therefore need to look for additional factors, which might inhibit the application of economic instruments.

\subsection{Lack of Political Support for Economic Instruments}

Environmental economists have proposed economic instruments since the 1960s. Until the beginning of the 1990s, however, economic instruments were actually introduced only in few instances in the OECD world (see table 3). Prominent early examples are the introduction of the so-called "emissions trading" in the US Clean Air Act of 1977, or the introduction of the German wastewater tax in 1978. During the 1970 s and 1980s some more environmental taxes were implemented in Europe, in particular in Scandinavian countries and the Netherlands, as well as in the United States, Canada, and Japan. In sum, however, there was no clear shift towards economic instruments.

The background for this hesitance to employ economic instruments was lack of political support on the side of almost all political actors. Environmental economists 
have provided several theoretical conjectures to explain the lack of acceptance on the side of the most important political actors. They propose three reasons why industry can be expected to reject tradable permits and taxes. First, compared to standards both permits and taxes are more expensive for them, because they must also pay for the residual pollution. Second, individual standards can usually be negotiated with the administration, while permits and taxes cannot be influenced. Third, interventionist measures often restrict competition for the "old firms" in a market, because newcomers are usually subject to stricter standards. Two explanations are given for governments' and politicians' hesitance: First, it is assumed that governments do not like to tie themselves down to precise political goals as is necessary with environmental taxes and licenses. A second speculation is that for politicians it is most important that the benefit of a political measure can be attributed to them. This is not the case with economic instruments. For the environmental administration, economic instruments imply a loss of competences and power because the instruments work automatically after introduction and because the administration does not have discretion in the implementation process. Finally, several reasons are given why environmental organizations and the general public are not in favor economic instruments. First, it is assumed for these groups that there is lack of information and comprehension of the functioning of economic instruments. Second, they are only interested in the benefit and not in the cost aspect of environmental policy. Third, economic instruments imply the explicit allocation of rights to pollute. This may offend values (e.g. Binder 1999: 187; Frey 1972, chapter VIII).

Whatever the reasons actually were, an empirical study of Holzinger shows that there was in fact a lack of acceptance of economic instruments during the 1980s. The preferences for economic instruments of various political actors were analyzed: government, environmental administration, industry, environmental organizations, and political parties. The study relates to the German political discourse and is based on document analysis and a questionnaire. The study shows that all actors preferred interventionist environmental policy by classical standard-setting to other instruments. Most actors bluntly rejected tradable permits. Similarly, most actors rejected environmental taxes. An exception was the Free Democratic Party, which was in favor of both permits and taxes. The Green Party accepted taxes only for the 
purpose of financing environmental expenses, not because of their allocation effects. Subsidies were openly demanded by industry, whereas all other actors rejected them - at least under this name. Using different terms, however, such as "environmental assistance", most actors actually proposed or accepted subsidies. In sum, until the middle of the 1980s there was little political support for economic instruments (Holzinger 1987, chapters 6 and 7). Although the study is restricted to Germany, given the small number of economic instruments actually introduced in the OECD countries in 1987 (see table 3) it can be assumed that the situation was not much different elsewhere.

This situation of general lack of support seems to have changed during the 1990s. Table 3 shows that the use of economic instruments has considerably increased between 1987 and 1997. There are now four times as many tradable permits, taxes, and charges as in 1987; the use of liability schemes and deposit systems has doubled, and subsidies have increased by $30 \%$. Although the OECD data have to be taken with care since they are partly based on questionnaires and self-classifications of the countries and only partly on scientific studies for the OECD, the trend is obvious at least for some of the instruments. 
Table 3. Use of economic instruments in selected OECD countries, 1987 and 1997

\begin{tabular}{|l|c|c|r|r|r|r|r|r|r|r|r|r|}
\hline \multirow{2}{*}{\begin{tabular}{l} 
Country \\
\cline { 2 - 12 }
\end{tabular}} & \multicolumn{2}{|c|}{$\begin{array}{l}\text { Tradable } \\
\text { Permits }\end{array}$} & \multicolumn{2}{|c|}{ Taxes** } & \multicolumn{2}{c|}{$\begin{array}{l}\text { Risk } \\
\text { Liability }\end{array}$} & \multicolumn{2}{c|}{ Charges } & \multicolumn{2}{c|}{ Subsidies } & \multicolumn{2}{c|}{$\begin{array}{c}\text { Deposit } \\
\text { Systems }\end{array}$} \\
\cline { 2 - 12 } & 1987 & 1997 & 1987 & 1997 & 1987 & 1997 & 1987 & 1997 & 1987 & 1997 & 1987 & 1997 \\
\hline Belgium* & 0 & 0 & 1 & 12 & 1 & 0 & 2 & 2 & 4 & 0 & 0 & 0 \\
Canada* & 0 & 2 & 0 & 5 & 0 & 2 & 2 & 16 & 1 & 3 & 1 & 1 \\
Denmark & 0 & 1 & 1 & 16 & 0 & 2 & 3 & 10 & 4 & 9 & 1 & 3 \\
Germany* & 0 & 0 & 3 & 6 & 1 & 1 & 3 & 6 & 9 & 0 & 1 & 1 \\
Finland & 0 & 0 & 2 & 11 & 1 & 3 & 2 & 14 & 9 & 9 & 1 & 2 \\
France & 0 & 1 & 4 & 6 & 1 & 0 & 2 & 10 & 8 & 1 & 1 & 1 \\
Greece & 0 & 0 & 0 & 5 & 0 & 0 & 2 & 5 & 2 & 3 & 0 & 0 \\
UK & 0 & 0 & 1 & 3 & 0 & 0 & 2 & 1 & 5 & 9 & 0 & 0 \\
Italy & 0 & 0 & 2 & 5 & 0 & 0 & 2 & 9 & 7 & 0 & 0 & 0 \\
Japan & 0 & 0 & 2 & 5 & 0 & 2 & 0 & 6 & 0 & 4 & 0 & 0 \\
Netherlands & 0 & 0 & 4 & 9 & 1 & 0 & 3 & 2 & 10 & 18 & 1 & 2 \\
Norway & 0 & 0 & 4 & 16 & 0 & 0 & 0 & 3 & 1 & 5 & 1 & 2 \\
Sweden & 0 & 0 & 5 & 17 & 0 & 2 & 1 & 10 & 1 & 7 & 1 & 2 \\
Switzerland* & 0 & 1 & 2 & 7 & 0 & 0 & 1 & 5 & 1 & 9 & 0 & 0 \\
USA* & 2 & 4 & 2 & 7 & 0 & 1 & 1 & 3 & 3 & 4 & 0 & 0 \\
Total & $\mathbf{2}$ & $\mathbf{9}$ & $\mathbf{3 3}$ & $\mathbf{1 3 0}$ & $\mathbf{5}$ & $\mathbf{1 3}$ & $\mathbf{2 6}$ & $\mathbf{1 0 2}$ & $\mathbf{6 5}$ & $\mathbf{8 1}$ & $\mathbf{8}$ & $\mathbf{1 4}$ \\
Poland & - & 1 & - & 9 & - & 0 & - & 3 & - & 1 & - & 1 \\
Czech Republic & - & 0 & - & 4 & - & 0 & - & 5 & - & 3 & - & 0 \\
Hungary & - & 0 & - & 12 & - & 0 & - & 13 & - & 0 & - & 0 \\
\hline
\end{tabular}

* Only federal level

** Data is based on OECD (1997)

Source: Opschoor and Vor, 1989; OECD, 1997, 1999; authors' calculation

The data suggest an increase of political acceptance of economic instruments within OECD states. An important background for this is the fact that green movements seem to have now accepted economic instruments as a means to achieve higher environmental quality. This became obvious when environmental NGO's supported the international emissions trading system for $\mathrm{CO}_{2}$ negotiated at the Kyoto conference and its follow-ups. A second factor is surely that the OECD has actively promoted the use of economic instruments (see section 2.1). However, if the use of economic instruments, and especially of environmental taxes and charges, has clearly grown at the national level of European OECD countries, why are there still so few economic instruments at the EU level?

\subsection{Institutional Particulars at the EU Level}

A closer look at the OECD data shows that in case of tradable permits the raise is not so impressing in absolute numbers. There are nine permit systems in 1997 compared to two in 1987. Five of the seven additional cases are found outside the 
EU, namely in the United States, Canada and Switzerland. Tradable permits are still relatively unusual in EU member countries and it is thus not surprising that we do not find a permit system at the EU level until 2000. In 2003, however, as a consequence of the international climate negotiations the EU has developed a permit system for $\mathrm{CO}_{2}$ emissions for its member states which will soon be implemented.

Similarly, the absolute number of strict liability instruments is small. They increased by eight new cases, five of them in non-EU countries, four in two small EU member states, namely Denmark and Finland. Therefore, in the case of risk liability it is again not surprising that there is no such instrument at EU level.

The number of deposit or refund systems (in most instances for beverage containers) is small, as well. Five out of six new deposit systems were introduced in EU member states. This can thus be seen as a typical European instrument. The EU level might also be affected by such an instrument, because products (and thus, competition) are concerned. In fact, in one instance, the Danish bottle case, the European Court of Justice was involved. However, the environmental value of deposit systems is much disputed. Furthermore, the national traditions with respect to the use of beverage containers vary widely. The idea of EU-wide deposit systems thus does not make much sense.

The increase of subsidies of about 30\% in the OECD countries is mirrored by the development at the EU level. The use of subsidies at the EU level rose from $2.9 \%$ in the period from 1987 to 1992 to $7.7 \%$ in the period from 1993 to 2000 (table 2). That is, subsidies have more than doubled. Thus, the EU is at least representative of the development in the OECD countries in this case.

In the cases of environmental taxes and charges the number of instances of application is four times as high in1997 than in 1987 for the OECD countries, whereas there are still no instances at EU level. For environmental charges this has a simple functional reason. Environmental charges and levies, for example for waste collection, drinking water and wastewater are usually employed at the local level. They are rather a price for a public service than a politically designed economic instrument with allocation functions. The EU itself does not provide such services and does not have the legal competence to impose charges on citizens in member states. Moreover, these services usually have no transboundary effects and no implications 
for trade and competition policy. The policies concerned do simply not affect the EU level. Consequently, there is no need for such provisions at the EU level.

We are therefore left with environmental taxes. This is the only instrument for which there is a considerable increase within OECD states and within EU member states (67 new instances after 1987), for which policies affecting the European level are concerned, and which constitutes a viable alternative to hierarchical intervention in many cases. Thus, all conditions for the European use of this instrument are fulfilled. The EU Commission actually wants to promote this instrument and acceptance of environmental taxes within the member states has obviously grown during the last decade. Why then is there not a single instance of an environmental tax at the EU level?

To our knowledge there was only one proposal for such a tax, namely the combined $\mathrm{CO}_{2}$ /Energy tax, developed by the Commission and negotiated in the Council from 1991 to 1993. The proposal failed, since the required unanimity of member states could not be achieved, given fierce resistance of concerned national industries. There were some other projects for environmental taxes developed by Commission officials, which, however, never reached the level of official negotiations within the Council. ${ }^{13}$

This story contains a clue for explanation: In tax matters, unlike in most other environmental matters, there is still unanimity in the Council required. Tax matters are very sensitive, because they are related to the notion of national sovereignty. It can be assumed to be anticipated by the Commission as well as by member states willing to introduce a particular environmental tax that unanimity is required and difficult to achieve whenever taxes are concerned. The actors hesitate to come up with such a proposal - especially after the experience of the failure in the $\mathrm{CO}_{2} /$ Energy case.

The explanations given here have been developed inductively. They are an attempt to understand why we do not see any economic instruments apart from subsidies at the EU level, although the Commission intended to promote them, although they are

13 Personal communication with Commission official. 
a practicable alternative to emission standards, and although the political support for these instruments obviously increased during the last decade.

\section{Conclusion}

In the current political and scientific discussion on EU governance, there is often an implicit assumption that the relevance of classical patterns of hierarchical intervention has been significantly reduced in favor of "new forms of regulation". It was our objective to analyze the extent to which new regulatory ideas have actually resulted in changes of regulatory patterns in EU environmental policy. As demonstrated by our empirical evidence, there is a broad gap between the political and scientific advocacy of new ideas and their actual implementation through corresponding changes in underlying policy instruments.

This gap can be explained by several factors. Harmonization requirements emerging from economic integration pose important restrictions to the substitution of interventionist instruments by context-oriented or economic instruments. Additional problems can be identified for the introduction of economic instruments. This holds true in particular for environmental taxes which interfere with the fiscal sovereignty of the member states. As a result, Council agreements are particularly difficult, not least because of the fact that unanimity still is the relevant decision-rule for all tax-related decisions. This explanation seems to be more important than the argument that member state resistance to economic instruments is primarily the result of potential costs of adjustment of national interventionist legacies to economic instruments advocated by the EU. This can be traced to the fact that OECD data indicate a considerable increase in the use of economic instruments at the domestic level. Against this backdrop, institutional adaptation costs can no longer be seen as the most decisive factor to account for the small share of economic instruments in EU environmental policy.

Both member state interests as well as institutional rules thus constitute important hurdles to changing environmental instruments at the European level. The leaves us with the question why the Commission, anticipating these hurdles, proposes such changes at all. Three factors might account for this development. 
First, it could be argued that the Commission deliberately advocated a large scale instrument change in the action programs in order to achieve its real, much les ambitious objective, namely the incremental enrichment of the existing regulatory framework by new policy tools. Second, the behavior of the Commission can be seen as a strategy of combining short-term and long-term political interests. In the short run, the Commission pursues its institutional self-interests by proposing policy proposals that are acceptable to the member states. This implies that the proposals necessarily depart from the ambitious declarations in the action programs. At the same time, however, the Commission is well aware of the fact that over time its repeated advocacy of new instruments might well have an impact on the preferences of national policy makers (e.g. by triggering effects of policy learning). This way, the Commission, in a long-term strategy, seeks to increase the legitimacy and acceptance of its reform proposals. 


\section{References}

Bea, F. X. (1973). "Die Verteilung der Lasten des Umweltschutzes nach dem Verursacherprinzip", Das Wirtschaftsstudium 2, 453-457.

Binder, K. G. (1999). Grundzüge der Umweltökonomie. München: Vahlen.

Collier, U. (1998). "The Environmental Dimensions of Deregulation: An Introduction", in: Collier, U (ed.), Deregulation in the European Union: Environmental Perspectives. London: Routledge, 3-24.

Endres, A. (2000). Umweltökonomie. Stuttgart: Kohlhammer.

European Commission (1984). Zehn Jahre Umweltpolitik der Europäischen Gemeinschaft. Brussels: March 1984.

European Commission (1995). Report of the Independent Group of Experts on Legislative and Administrative Simplification. Brussels: Commission of the European Union.

European Commission (1996). Implementing Community Environmental Law. Communication to the Council of the European Union and the European Parliament. Brussels: Commission of the European Union.

Frey, B. S. (1972). Umweltökonomie. Göttingen: Vandenhoeck \& Ruprecht.

Haigh, N. eds. (2000). The Manual of Environmental Policy: the EC and Britain. London: Catermill Publishing.

Héritier, A. (2002). "New Modes of Governance in Europe: Policy-making Without Legislating?" in: Héritier, A. (ed.), The Provision of Common Goods: Governance Across Multiple Arenas. Boulder: Rowman \& Littlefield.

Héritier, A., Knill, C. und S. Mingers (1996). Ringing the Changes in Europe. Regulatory Competition and the Transformation of the State. Berlin: de Gruyter.

Holzinger, K. (1987). Umweltpolitische Instrumente aus der Sicht der staatlichen Bürokratie. IfoStudien zur Umweltökonomie 6. München: Ifo-Institut für Wirtschaftsforschung.

Holzinger, K. (2002). "The Provision of Transnational Common Goods: Regulatory Competition for Environmental Standards", in: A. Héritier (ed.), Common Goods: Re-inventing European and International Governance. Lanham: Rowman and Littlefield, 57-79.

Ifo-Institute for Economic Research (1989). The Polluter Pays Principle and Environmental Impacts. Munich: September 1989.

Johnson, S. P. und G. Corcelle (1989). The Environmental Policy of the European Communities. London: Graham and Trotman.

Jordan, A. (1999). "The Implementation of EU Environmental Policy: A Problem Without a Political Solution? Environment and Planning C", Government and Policy 17, 69-90.

Jordan A., Wurzel R. and Zito, A. (2003). „European Governance and the Transfer of "New" Environmental Policy Instruments in the European Union", Public Administration, 81:3, 555574.

Knill, C. und A. Lenschow, eds. (2000). Implementing EU Environmental Policy. New Directions and Old Problems. Manchester: Manchester University Press. 
Krämer, L. (1996). "Defizite im Vollzug des EG-Umweltrechts und ihre Ursachen", in: Lübbe-Wolff, G. (ed.). Der Vollzug des europäischen Umweltrechts. Berlin: Erich Schmidt Verlag, 7-36.

Lenschow, A. (1999). "Transformation in European Environmental Governance", in: Kohler-Koch, B. und R. Eising (eds.), The Transformation of Governance in the European Union. London: Routledge, 39-60.

Mol, A. P., Lauber, V. und D. Liefferink, eds. (2000). The Voluntary Approach to Environmental Policy. Oxford: Oxford University Press.

OECD (1981a). "An Assessment of the Implementation of the Polluter-Pays-Principle". Environment Committee, Group of Economic Experts. Paris: Mai 1981.

OECD (1981b). "The Implementation of the Polluter-Pays-Principle: A Review of Member Countries" Practises" (A Summary of the Replies and the Replies from Member Countries). Paris: Oktober 1981.

OECD (1994). Managing the Environment: The Role of Economic Instruments. Paris: OECD.

OECD (1997). Evaluating Economic Instruments for Environmental Policy. Paris: OECD.

OECD (1999). "Economic Instruments for Pollution Control and Natural Resources Management in OECD Countries: A Survey". Paris: OECD. Working Party on Economic and Environmental Policy Integration.

Opschoor, J. B. und H. B. Vos (1989). "The Application of Economic Instruments for Environmental Protection in OECD Countries. Final Report”. Paris: 1989.

Rehbinder, E. und R. Stewart (1985). Environmental Protection Policy. Integration Through Law. Berlin: de Gruyter.

Rittberger, B. and J. Richardson (2003). "Old Wine in New Bottles? The Commission and the Use of Environmental Policy Instruments", Public Administration, 81:3, 575-606.

Scharpf, F.W. (1997). "Introduction: The Problem-solving Capacity of Multi-level Governance", Journal of European Public Policy, 4, 520-538.

Siebert, H. (1976). Analyse der Instrumente der Umweltpolitik. Göttingen: Otto Schwartz \& Co. (in cooperation with W. Vogt).

Weale, A. et al. (2000). Environmental Governance in Europe. An Ever Closer Ecological Union. Oxford: Oxford University Press. 


\section{Contact}

Prof. Dr. Christoph Knill

Chair of Comparative Public Policy and Administration

Box D 91

D-78457 Konstanz

Germany

Phone ++497531885597

Fax ++ 497531882381

christoph.knill@uni-konstanz.de

University of Konstanz

(7) www.uni-konstanz.de

Department of Politics and Management

(7) www.uni-konstanz.de/sektionen/polver

Chair of Comparative Public Policy and Administration

(7) www.uni-konstanz.de/FuF/Verwiss/knill

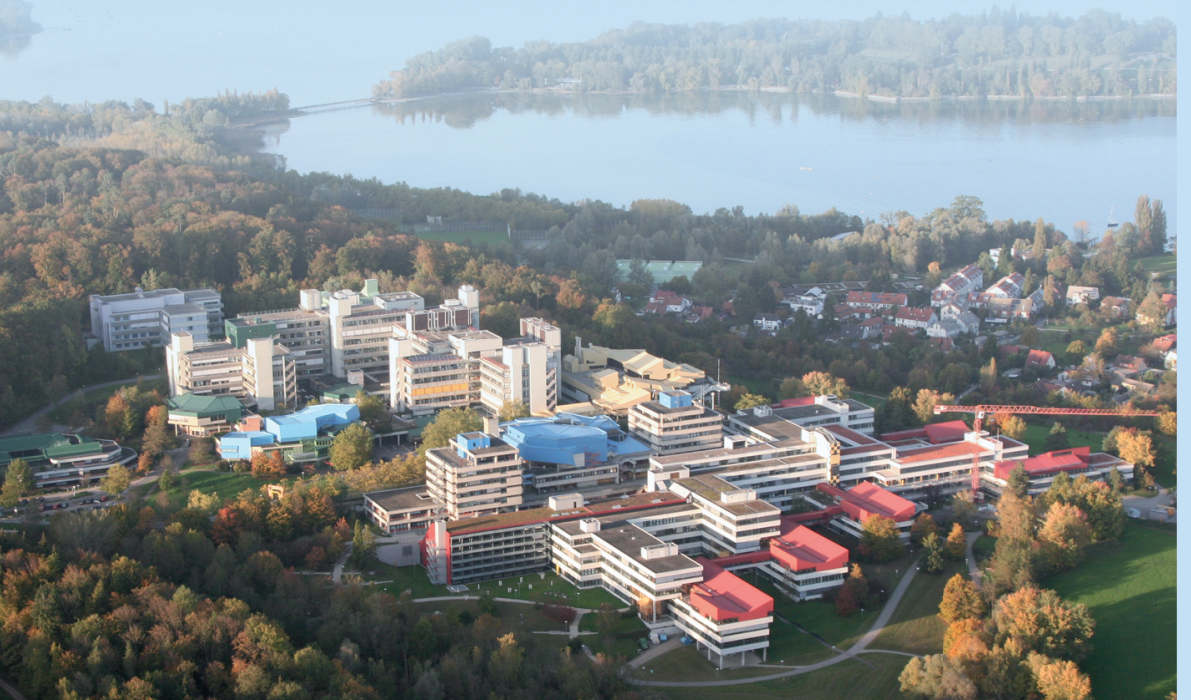

